\title{
The negative impact of coal mining company on health, environment, climate change, economic sustainability and macroeconomic
}

\author{
Rofikoh Rokhim ${ }^{1, *}$, Wardatul Adawiyah ${ }^{1}$, and Ruri Eka Fauziah Nasution ${ }^{1}$ \\ ${ }^{1}$ Department of Management Faculty of Economics and Business, Universitas Indonesia, 16424, Depok, \\ Indonesia
}

\begin{abstract}
This paper aims to analyze the impact of mining company on financial measurement through Economic Value Added (EVA) and non financial measurement (i.e. health, environment, climate change, economic sustainability, and macroeconomic variables). This study uses qualitative and quantitative analysis method. Result from this study shows that coal mining does not provided added value to the economy, moreover it also has negative impact on environment by contributing largest carbon dioxide emission. In addition, to open new sites for coal mining, coal miners must do deforestation. In terms of health impact, this study find that local people who live near the coal mining site are exposed to health problem. Furthermore, there is also potential conflict with local people. Coal mining also has negative impact on trade balance, exchange rate, and the growth of other sector, particularly when the commodity prices decrease.
\end{abstract}

\section{Introduction}

After the decline of Indonesia's petroleum production, the coal mining industry has experienced a very rapid development. This development was also supported by international organization. The establishment of SDG does not make it legally to the country members, but the mining industry come into this context by its global presence and frequent location within ecologically sensitive and less developed areas [1].

Coal is one of the cheapest sources of energy for electricity. The demand for coal is predicted to increase following the expected increase in electricity demand three times from 2011-2035 in ASEAN countries. Coal demand is expected to increase by $4.8 \%$ with demand for electricity use in Indonesia is expected to increase from 76 million tons in 2015 to 151 million tons in 2022. The Government of Indonesia (GoI) is currently focusing on achieving energy security with coal as one of the main source of energy that can be used to reduce the dependency on oil production. Nevertheless, there is a growing trend on coal phased-out showed by the international community due to its negative impacts. The negative impacts of coal mining can be viewed from environmental, health, economic sustainability and macroeconomic variables. Considering the aforementioned background, a study is needed to

\footnotetext{
* Corresponding author: rofikoh.rokhim@ui.ac.id
} 
discuss and analyze the negative impacts of coal mining, which later become the rational of the implementation of coal production quotas. Thus, this study aims to analyze the impact of mining company on financial measurement through Economic Value Added (EVA) and nonfinancial measurement (i.e. health, environment, climate change, economic sustainability, and macroeconomic variables).

\section{Literature review}

\subsection{Coal mining and its cost}

Coal is considered as the dirtiest source of energy, which contributes to the largest $\mathrm{CO}_{2}$ emissions. Coal is mined by exploitation activities and requires large amount of investment. Coal mining includes several activities, which include land clearing, benching systems, material handling and hauling [2]. These activities cause negative damage to the environment since it changes the ecosystem and increases environmental pollution. The environmental costs arising from coal mining is discussed below.

Table 1. Environmental Costs Arising From Coal Mining.

\begin{tabular}{|l|l|}
\hline \multicolumn{1}{|c|}{ Cost Type } & \multicolumn{1}{c|}{ Cost Component } \\
\hline Cost of forest area use & - Costs of loss of water absorption \\
& - Costs of carbon release \\
& - Costs of oxygen loss \\
& - Costs of forest rehabilitation \\
& - Costs of forest logging \\
\hline Individual cost in society & - Medical treatment costs due to pain (in the hospital) \\
& - Medical expenses \\
& - Accidental costs \\
& - Costs arise from disturbed activities \\
\hline Cost of loss of river benefits & - Costs of clean water \\
\hline Flood prevention costs & - Cost of Flood Polder construction \\
& - Cost of Flood Mitigation Plans \\
\hline
\end{tabular}

\subsection{Approaches to analysis of EVA}

Alfred Marshall that appeared in paper written by Bluszcz and Kijewska in 2016 has introduced the theory of Economic Value Added (EVA) in 1890. He stated that EVA means the remaining profits after deducting interest on his capital at the current rate [3]. Brigham and Houston defined EVA as an actual economic profit estimation of a company in a specified year and is different from accounting profit [4]. Economic value added is applied in this study as a tool to investigate whether the coal mining provides added value to the economy or not. In general, EVA can be calculated by subtracting the potential revenue with its cost.

The formula of economic value added can be expressed as follows [5]:

$$
\begin{aligned}
& E V A=N O P A T-W A C C \cdot I C \\
& E V A=(R O I C-W A C C) \cdot I C
\end{aligned}
$$

where: NOPAT is Net Operating Profit After Taxes, IC is Invested Capital at the Beginning of the Year, ROIC is Return on Invested Capital, and WACC is Weighted Average Cost of Capital. The formula to calculate WACC is written as follows:

$$
W A C C=r_{E} \cdot \frac{E}{V}+r_{D} \cdot(1-T) \cdot \frac{D}{V}
$$


where: $r_{E}$ is cost of equity, $r_{D}$ is cost of debt (interest-bearing), $E$ is Equity, $D$ is interest-bearing debt, $T$ is tax rate and $V$ is enterprise value equal to the sum of invested equity and interestbearing debt. The formula to calculate ROIC is written as follows:

$$
R O I C=\frac{N O P A T}{I C}=\frac{N O P A T}{S} \cdot \frac{S}{I C}
$$

where: $\mathrm{S}$ is sales (sales revenue), $\frac{N O P A T}{S}$ is profit margin, and $\frac{S}{I C}$ is capital invested turnover.

Then, EVA can be calculated as follows:

$$
E V A=\left(\frac{N O P A T}{S} \cdot \frac{S}{I C}-W A C C\right) \cdot I C
$$

\section{Research methodology}

The research uses qualitative and quantitative method to analyze the result. The quantitative method is used to analyze the impact of coal mining in financial measurement, which is in this paper is use Economic Value Added (EVA) as a proxy for financial measurement. The qualitative method is used to analyze the impact of coal mining for non-financial measurement i.e. health, environmental, climate change, sustainable economy, and macroeconomic impacts.

\section{Analysis of result}

\subsection{Economic value added of coal mining}

Potential revenue from coal mining can be calculated using several assumptions listed below:

1. A mining area of 257 hectares is estimated to produce IDR 20 billion

2. Revenue from coal mining is estimated to grow by $5 \%$ per year

3. A contribution to the government in the form of regional tax royalty, VAT and income tax is estimated $25 \%$.

4. Payment to contractors, suppliers and other costs is $60 \%$ of revenue

5. Employee and CSR service fees are estimated 5\% of revenue

The cost arises from coal mining are estimated using the assumptions as follow:

1. Value of forest area use

a. Water value

i. It is assumed that the use of water is $730,994 \mathrm{~m}^{3}$ with price of IDR25,000 per liter and a $5 \%$ increase per year

ii. The average population around the office site is 300 thousand people

b. Carbon value

i. The mining area for one site is assumed 257 hectares

ii. The amount of carbon produced is 67,591 tons with price of IDR122,260 per ton and a $5 \%$ increase per year

c. Oxygen Value

i. The number of felled trees for the mining site is assumed 23,130,000 trees where the amount of oxygen produced by each tree per day is $1.2 \mathrm{~kg}$. The oxygen density is 1.429 gram/liter.

ii. The price of oxygen is IDR25 thousand per liter with 5\% increase per year

2. Cost of trees rehabilitation and costs of logging

a. The price of tree rehabilitation is IDR 11,695,000 with a 5\% increase per year

b. The price of felling trees is IDR9,629 per cubic meter

3. Individual costs in society 
a. The cost of pulmonary TB outpatient is IDR135,000

b. The cost of ill treatment (hospitalization) is IDR5,425,000 (inpatient pulmonary TB), IDR532,500 (self treatment), IDR577,500 (accident) and IDR189,194 (activity disrupted)

4. Costs of clean water

a. The monthly average spending for clean water is IDR76,028 per household

b. The average population around the site is 300 thousand people

5. Costs of flood prevention

a. The cost of flood polder construction is IDR230,846,715

b. The cost in preparing risk mitigation plan is IDR11,542,335,766

Based on the assumption discussed above, calculation of EVA for coal mining can be estimated as shown in the following table:

Table 2. Economic Value Added of coal mining (in million Rupiah).

\begin{tabular}{|c|c|c|c|c|c|}
\hline Year & 1 & 2 & 3 & 4 & 5 \\
\hline \multicolumn{6}{|l|}{$\begin{array}{l}\text { Potential Revenue of Coal } \\
\text { Mining } \\
\text { a. Contribution to Government }\end{array}$} \\
\hline \multicolumn{6}{|l|}{ - Local Government } \\
\hline Regional Tax Royalties & 3,150 & 3,308 & 3,473 & 3,647 & 3,829 \\
\hline \multicolumn{6}{|l|}{ - Central Government } \\
\hline Value added tax (PPN) & 525 & 551 & 579 & 608 & 638 \\
\hline $\begin{array}{l}\text { b. Payments to contractors, } \\
\text { suppliers and other services }\end{array}$ & 12,600 & 13,230 & 13,892 & 14,586 & 15,315 \\
\hline $\begin{array}{l}\text { c. Employee and CSR service } \\
\text { fees }\end{array}$ & 1,050 & 1,103 & 1,158 & 1,216 & 1,276 \\
\hline Total Potential Revenue & 17,325 & 18,191 & 19,101 & 20,056 & 21,059 \\
\hline \multicolumn{6}{|l|}{$\begin{array}{l}\text { The Cost of Coal Mining } \\
\text { 1. Value of Forest Area Use }\end{array}$} \\
\hline a. Water Value & 18,275 & 19,189 & 20,148 & 21,155 & 22,213 \\
\hline b. Carbon Value & 8,264 & 8,677 & 9,111 & 9,566 & 10,045 \\
\hline c. Oxygen Value & $356,969,916$ & $374,818,412$ & $393,559,332$ & $413,237,299$ & $433,899,164$ \\
\hline $\begin{array}{l}\text { d. Forest Rehabilitation } \\
\text { Value }\end{array}$ & 15,013 & - & - & - & 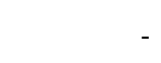 \\
\hline e. Value of Deforestation & 24,746 & - & - & - & - \\
\hline Total Cost of Forest Area Use & $357,036,213$ & $374,846,277$ & $393,588,591$ & $413,268,021$ & $433,931,422$ \\
\hline \multicolumn{2}{|l|}{$\begin{array}{l}\text { a. Sick Treatment Costs } \\
\text { (Outpatient) }\end{array}$} & & & & \\
\hline $\begin{array}{l}\text { - The Cost of Pulmonary } \\
\text { TB Outpatient }\end{array}$ & 40,500 & 42,525 & 44,651 & 46,884 & 49,228 \\
\hline \multicolumn{6}{|l|}{$\begin{array}{l}\text { b. Sick Treatment Cost } \\
\text { (Hospitalization) }\end{array}$} \\
\hline $\begin{array}{l}\text { - The Cost of Pulmonary } \\
\text { TB Inpatient }\end{array}$ & $1,627,500$ & $1,708,875$ & $1,794,319$ & $1,884,035$ & $1,978,236$ \\
\hline c. Self Treatment & 159,750 & 167,738 & 176,124 & 184,931 & 194,177 \\
\hline d. Accident & 176,250 & 185,063 & 194,316 & 204,031 & 214,233 \\
\hline e. Activity Disrupted & 56,758 & 59,596 & 62,576 & 65,705 & 68,990 \\
\hline Total Individual Cost in Society & $2,060,758$ & $2,163,796$ & $2,271,986$ & $2,385,585$ & $2,504,864$ \\
\hline \multicolumn{6}{|l|}{ 3. Cost of Clean Water } \\
\hline $\begin{array}{l}\text { a. Cost of losing the benefits of } \\
\text { biological resources }\end{array}$ & - & - & - & - & - \\
\hline b. Cost for Clean Water & 68,425 & 71,846 & 75,439 & 79,211 & 83,171 \\
\hline Total Cost of Clean Water & 68,425 & 71,846 & 75,439 & 79,211 & 83,171 \\
\hline \multicolumn{6}{|l|}{ 4. Cost of Flood Prevention } \\
\hline $\begin{array}{l}\text { a. Cost of Flood Polder } \\
\text { Construction }\end{array}$ & 63,252 & - & - & - & - \\
\hline $\begin{array}{l}\mathrm{b} \text {. The cost in preparing } \\
\text { risk mitigation plan }\end{array}$ & $3,162,600$ & - & - & - & \\
\hline
\end{tabular}




\begin{tabular}{lrrrrr}
\hline Year & $\mathbf{1}$ & $\mathbf{2}$ & $\mathbf{3}$ & $\mathbf{4}$ & $\mathbf{5}$ \\
\hline Total Cost of Flood Prevention & $\mathbf{3 , 2 2 5 , 8 5 2}$ & - & - & - & - \\
\hline Total Cost & $\mathbf{3 6 2 , 3 9 1 , 2 4 8}$ & $\mathbf{3 7 7 , 0 8 1 , 9 2 0}$ & $\mathbf{3 9 5 , 9 3 6 , 0 1 6}$ & $\mathbf{4 1 5 , 7 3 2 , 8 1 7}$ & $\mathbf{4 3 6 , 5 1 9 , 4 5 7}$ \\
\hline Total Potential Revenue & 17,325 & 18,191 & 19,101 & 20,056 & 21,059 \\
Total Cost & $362,391,248$ & $377,081,920$ & $395,936,016$ & $415,732,817$ & $436,519,457$ \\
Opportunity Cost of Capital & $12 \%$ & $12 \%$ & $12 \%$ & $12 \%$ & $12 \%$ \\
Capital Charge & $43,486,950$ & $45,249,830$ & $47,512,322$ & $49,887,938$ & $52,382,335$ \\
\hline Economic Value Added & $\mathbf{- 4 3 , 4 6 9 , 6 2 5}$ & $\mathbf{- 4 5 , 2 3 1 , 6 3 9}$ & $\mathbf{- 4 7 , 4 9 3 , 2 2 1}$ & $\mathbf{- 4 9 , 8 6 7 , 8 8 2}$ & $\mathbf{- 5 2 , 3 6 1 , 2 7 6}$ \\
\hline
\end{tabular}

Table 2 depicts that the costs incurred from coal mining are much higher than the potential revenue generated. The result of EVA indicates that coal mining does not provide economic value to the community around the site. In addition to EVA calculation, the following subsections will discuss negative impacts of coal mining on health, environment, climate change, sustainable economics and macroeconomics.

\subsection{Non-financial impact}

\subsubsection{Health impacts}

Research conducted by Harvard University in 2016 found that the use of coal for power plants (Pembangkit Listrik Batubara, PLBB) can cause 6,500 premature deaths each year. It is estimated that every coal power plant construction with a capacity of 1,000 MW will have an impact on the deaths of 600 residents every year. Regarding the plan on building a large number of coal power plans (PLBB), the number of deaths is estimated to reach 28,300 people per year [6]. The high mortality rate is caused by the risk of chronic diseases in adults as well as acute respiratory diseases in children. Coal-fired itself is one of the main contributors to air pollution. Lung cancer, stroke, heart disease, to respiratory diseases are few example of diseases results from coal burning [7].

\subsubsection{Environmental Impacts}

In addition to the health impact, environmental consideration has become a predominant rational for coal phasing-out. The coal mining in Indonesia is concentrated in Kalimantan, in particular East Kalimantan and South Kalimantan. Results of spatial analysis conducted by Greenpeace show that the official mining area in South Kalimantan has reached an area of 1 million hectares (Mha) or one third of the area of South Kalimantan [8]. Environmental impacts arising from coal start from mining activity to the consumption activity through the burning process. Land clearing for mining has also contributed to deforestation. In addition, coal content that contains a lot of pollutants such as heavy metals creates acidic waste. In addition, the fertile soil layer in the remaining coal mining area erodes and leaves the land difficult to be reprocessed. Another impact of land damage is land inability to absorb water perfectly that potentially can cause flood.

\subsubsection{Climate change impacts}

Climate change has become one of indirect driving factors of coal phasing-out urgency in Indonesia. In Indonesia, coal combustion has contributed $40 \%$ of carbon dioxide emissions related to energy in 2014 [9]. This number is expected to increase by more than 800 million tons by 2035 [10]. The use of coal through the combustion process will produce carbon dioxide and nitrogen oxides. Coal is the largest contributor to greenhouse gases, with a global share of carbon dioxide emissions has reached 44\% [11]. Both compounds are significant contributors to climate change. The high number of compounds in the atmosphere will increase the global 
temperature [12]. The higher the temperature will accelerate the ice melting process in the North Pole and the South Pole, which, in turn, will affect the overall ecosystem balance. Based on trends from 1960 to 2010, Indonesia recorded an increase in air temperature [13]. Global warming that impacts climate change will provoke extreme weather conditions i.e. heavy rain, floods, storms, and droughts. Disasters such as floods and storms will certainly be more severe if experienced by countries with low income, since it is increasingly difficult in terms of providing resources for disaster management [14]. Climate change not only has the potential to disasters due to extreme weather, but also can threaten food security due to increasingly unpredictable weather [15].

\subsubsection{Sustainable economic impacts}

There are several indicators to measure economic sustainability. In this study, there are two indicators used, namely (1) efficiency, and (2) long-term benefits. Eco-efficiency indicates how efficient economic activity by considering the resources used. Through the concept of ecoefficiency, resources are used in an efficient way with the purpose to minimize the impact of pollution. Under eco-efficiency concept, both resources and the production process are expected to be more productive. In the case of coal consumption, the concept of eco-efficiency is important since coal is a non-renewable fossil source of energy. The continuous consumption of coal will certainly deplete the coal reserves owned by Indonesia. In the short term, there are economic benefits from using coal. In terms of availability, coal is source of energy with abundant reserves. In addition, the production costs of coal production, especially in Indonesia, are relatively low. However, it is argued that the benefits of using coal are only for short-term period. When viewed in terms of coal resources availability, it is found that not all available coal reserves can be mined economically. Indonesia's coal reserves that can be mined economically (proven reserves) are estimated only around 8.3 billion tons, which is expected to last only until 2036 [16].

\subsubsection{Macroeconomic impacts}

In general, the coal mining industry has an impact on several macroeconomic variables, namely (1) Gross Domestic Product and Multiplier Effects, (2) Balance of payments and exchange rates, (3) Employment and (4) Impacts on other Sectors. The coal mining industry has contributed approximately $2.4 \%$ of Indonesia's GDP, which put this sector at the second largest contributor after oil and gas. The contribution of coal mining sector to non-tax revenues (Penerimaan Negara Bukan Pajak or PNPB) is IDR26.3 trillion, which represent $81 \%$ of PNPB from mining sector. Coal mining activities are claimed to have a multiplier effect of 1.6-1.9 times on the economy [17]. However, it is argued that this contribution is relatively very small compared to the negative impacts of the sector. In addition, this contribution has not considered the impact of the coal-mining sector on other macroeconomic variables. Since 2012 Indonesia has been the largest coal exporting country in the world. The economic slowdown in coal importing countries such as China has led a decline in coal demand. In addition, the growing trend of reducing coal consumption due to its environmental impacts has led the decline in coal demand. As the consequences, there is an excess of coal supply on the international market. Coal prices have decrease significantly from US\$127/ton in 2011 to US \$50.9/ton in $2016^{[18]}$. The decline in coal prices inevitably affected Indonesia's balance of payments which results in a decline in coal export revenues. In 2012, Indonesia's current account recorded a deficit as a result of declined commodity prices. The current account deficit in 2012 was followed by rupiah depreciation. This indicates that a large dependence on coal exports will affect the stability of exchange rate. The total mining industry workforce had increased from 715,000 in 2007 to $1,134,000$ in 2012 . This number decreased by $3.96 \%$ in 2013 to $1,089,000$ people. 
Notwithstanding the industry absorbs large number of workforce, local population perceives this positive impact only in the beginning of the process. At the beginning of land clearing activities for mining areas, some jobs were created such as logging-and-land-clearing related job for new mining concessions. However, jobs with high-skilled requirement such as heavy machinery operation and other skilled personnel required in the process of land clearing and completion of land clearing, are filled by workforce from other regions that will add pressure on scarce resources [19].

\section{Conclusion}

Since the 2000s coal production in Indonesia has a rapid increase. Of the total production, the domestic market has only absorbed less than $10 \%$ of coal production. Most of Indonesia's coal production is exported abroad, making Indonesia the largest coal exporting country in the world. Despite the abundance of reserves and low cost of production, coal is the dirtiest source of energy that contributes to the largest $\mathrm{CO}_{2}$ emissions. This fact has encouraged developedcountries i.e. Canada, Austria and the United Kingdom to reduce coal production and switch to renewable energy. Based on the calculation of EVA, this study argues that coal mining does not provide added value to the economy. In addition, the negative impact of coal production is very broad which includes environmental impacts, health, and economic sustainability to macroeconomic conditions. All of these negative impacts will eventually become the cost of externalities that must be paid by the community. In addition, the economic benefits derived from coal production are only for short-term. Therefore, by taking into account the magnitude of the negative impacts caused by coal discussed above, the government needs to set coal production quotas and switch to renewable energy sources.

\section{Acknowledgements}

This is research collaboration with WALHI-non government organization (NGO) that focus on protecting environment in Indonesia. Thank you to the WALHI for the constructive comments.

\section{References}

1. R.F. de Mesquita, A. Xavier, B. Klein, F.R.N. Matos, Geo-Resources Environment and Engineering (GREE) 2, 29-34 (2017)

2. T.A. Fachlevi, E.I.K. Putri, S.M. Simanjuntak, Risalah Kebijakan Pertanian Dan Lingkungan: Rumusan Kajian Strategis Bidang Pertanian dan Lingkungan 2, 2, 170-179 (2016)

3. A. Bluszcz, A. Kijewska, Archives of mining sciences, 61, 1, 109-123 (2016).

4. Brigham, F. Eugene, F. Joel, Houston, Manajemen Keuangan (Erlangga, Jakarta, 2001)

5. G. Hawawini, C. Viallet, Finance for Executive. Managing for Value Creation (SouthWestern Cengage Learning, Mason, OH, 2007)

6. Greenpeace, Human Cost of Coal Power: How Coal-Fired Power Plants Threaten The Health of Indonesian (2015)

7. Greenpeace, Greenpeace Briefing Paper: The True Cost of Coal (2014)

8. Greenpeace, Coal Mine Polluting South Kalimantan's Water (2014)

9. British Petroleum, Statistical Review of World's Energy 2015 (2015)

10. P. Tharakan, Summary of Indonesia's Energy Sector Assessment.ADB Papers on Indonesia No. 9 (Asian Development Bank, 2015)

11. Massachusetts Institute of Technology. The Future of Coal Summary Report (2007) 
12. E. Burt, P. Orris, S. Buchanan, Scientific Evidence of Health Effects from Coal Use in Energy Generation. Healthcare Research Collaborative dan University of Illinois at Chicago School of Public Health (2013)

13. P. Tharakan, Summary of Indonesia's Energy Sector Assessment. ADB Papers on Indonesia No. 9. (Asian Development Bank, 2015)

14. A. Costello, M. Abbas, A. Allen, S. Ball, S. Bell, R. Bellamy, et al., Lancet England, 373, 9676, 1693-1733 (2009)

15. U.S. Environmental Protection Agency, EPA's Endangerment Finding: Health Effects. (2009)

16. Pricewaterhouse Coopers Indonesia Advisory. Supplying and Financing Coal-Fired Power Plants in the 35 GW Programme (2016)

17. Asosiasi Penambang Batubara Indonesia. Royalty Report Duty (2013)

18. Pricewaterhouse Coopers Indonesia Advisory, Supplying and Financing Coal-Fired Power Plants in the 35 GW Programme (2016)

19. Greenpeace, Bagaimana Pertambangan Batubara Melukai Perekonomian Indonesia (2014) 